University at Albany, State University of New York

Scholars Archive

Psychology Faculty Scholarship

Psychology

$11-17-2014$

\title{
Psychological mechanisms underlying support for juvenile sex offender registry laws: Prototypes, moral outrage, and perceived threat
}

\author{
Margaret C. Stevenson \\ University of Evansville \\ Cynthia J. Najdowski \\ University at Albany, State University of New York, cnajdowski@albany.edu \\ Jessica M. Salerno \\ Arizona State University
}

The University at Albany community has made this article openly available.

Please share how this access benefits you.

Bette L. Bottoms

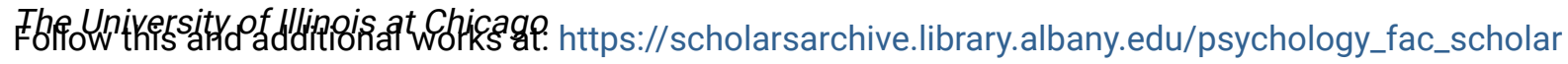

Part of the Criminal Law Commons, Criminology and Criminal Justice Commons, Developmental

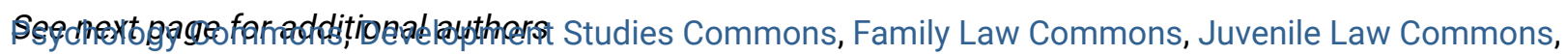
Law and Psychology Commons, Personality and Social Contexts Commons, Public Policy Commons, Sexuality and the Law Commons, Social Control, Law, Crime, and Deviance Commons, and the Social Psychology Commons

\section{Recommended Citation}

Stevenson, Margaret C.; Najdowski, Cynthia J.; Salerno, Jessica M.; Wiley, Tisha R.A.; Bottoms, Bette L.; and Farum, Katlyn S., "Psychological mechanisms underlying support for juvenile sex offender registry laws: Prototypes, moral outrage, and perceived threat" (2014). Psychology Faculty Scholarship. 25. https://scholarsarchive.library.albany.edu/psychology_fac_scholar/25

This Article is brought to you for free and open access by the Psychology at Scholars Archive. It has been accepted for inclusion in Psychology Faculty Scholarship by an authorized administrator of Scholars Archive.

Please see Terms of Use. For more information, please contact scholarsarchive@albany.edu. 
Authors

Margaret C. Stevenson, Cynthia J. Najdowski, Jessica M. Salerno, Tisha R.A. Wiley, Bette L. Bottoms, and Katlyn S. Farum

This article is available at Scholars Archive: https://scholarsarchive.library.albany.edu/psychology_fac_scholar/25 
PRE-PRINT. This paper is not the copy of record and may not exactly replicate the authoritative document published in the journal.

Running head: JUVENILE REGISTRY LAWS

Revised and resubmitted for review at Behavioral Sciences and the Law on October 30, 2009

Psychological Mechanisms Underlying Support for Juvenile Sex Offender Registry Laws:

Prototypes, Moral Outrage, and Perceived Threat

Jessica M. Salerno and Cynthia J. Najdowski

The University of Illinois at Chicago

Margaret C. Stevenson

University of Evansville

Tisha R. A. Wiley, Bette L. Bottoms, Roberto Vaca, Jr., and Pamela S. Pimentel The University of Illinois at Chicago

Authors' note: We thank Maria Vargas, Kristen Roy, and Rachel Doran for their invaluable research assistance; Nicole Pittman and Peter Parry for their consultation regarding legal issues; Nancy Hablutzel, Mary McDermott, and the Illinois State Bar Association for facilitating data collection with the family law attorneys; and Randy Roberts and the Cook County State's Attorney's Office for 
facilitating data collection with the prosecutors. Correspondence should be addressed to Bette L. Bottoms via electronic mail at bbottoms@ uic.edu or by surface mail at Department of Psychology, University of Illinois at Chicago, 1007 W. Harrison St. (MC 285), Chicago, IL 60607-7137. 


\begin{abstract}
In three studies, we investigated support for applying sex offender registry laws to juveniles. Family law attorneys supported registry laws less for juveniles than for adults. Laypeople and prosecutors supported juvenile and adult sex offender registration equally — even though they perceived juveniles as generally less threatening than adults (Study 1) — because most people spontaneously envision a severe sex offender prototype regardless of offender age (Study 2). People are less supportive of registry laws, however, when they envision less severe prototypes spontaneously (Study 2) or when induced to do so (Study 3). Effects of offender age, offender prototypes, and offense severity were mediated by perceptions of threat posed by the juvenile sex offender (i.e., utilitarian concerns). The effect of offense severity was also mediated by moral outrage (i.e., retributive concerns).
\end{abstract}


Psychological Mechanisms Underlying Support for Juvenile Sex Offender Registry Laws:

Prototypes, Moral Outrage, and Perceived Threat

In 2006, the Sex Offender Registration and Notification Act (SORNA; 42 U.S.C. § 16911; i.e., The Adam Walsh Child Protection and Child Safety Act of 2006) mandated that all states place convicted sex offenders on an online registry, including juvenile sex offenders who are convicted in adult criminal court or who are at least 14 years old and adjudicated delinquent in juvenile court for attempted or committed sex offenses involving aggravating circumstances (e.g., use of force, threat of serious violence). These are minimum guidelines: States have enacted more inclusive policies such as registering younger juveniles and those who commit less serious crimes. In fact, only four states explicitly prohibit the registration of juveniles under age 14 (Indiana, Ohio, Oklahoma, and South Dakota), and juveniles as young as 7 may be placed on sex offender registries in states such as North Dakota (for a review of state laws, see Salerno et al., in press). In Illinois, where the current research was conducted, registration is required for the same offenses regardless of whether the offender is a juvenile or adult, and there is no minimum age for registration. Information about juvenile sex offenders is provided quarterly to daycare centers and schools and becomes public on the Internet after offenders turn 17 years old (Illinois State Police, 2006).

Sex offender registration laws were implemented in the United States with the best of intentions - to protect children from dangerous sexual predators (for a review, see Chaffin, 2008; Trivits \& Reppucci, 2002). Unfortunately, there is little scientific evidence that registration actually protects children by decreasing offender recidivism (Adkins, Huff, \& Stageberg, 2000; Letourneau \& Armstrong, 2008; Sandler, Freeman, \& Socia, 2008; Schram \& Milloy, 1995). Further, registration has unintended negative effects on sex offenders, such as mental distress, harassment, and social isolation (Levenson \& Cotter, 2005; Levenson, D’Amora, \& Hern, 2007; Robbers, 2009; Schiavone \& Jeglic, 2008; Tewksbury, 2005; Tewksbury \& Lees, 2006), which might make these offenders more likely to reoffend (Letourneau \& Miner, 2005). The application of sex offender registry laws to juveniles is of 
particular concern. Juvenile sex offenders differ in important ways from adult sex offenders: They are more amenable to rehabilitation and recidivate at lower rates (7\%; Caldwell, 2009) than adult sex offenders (20-40\%; Alexander, 1999; Hanson \& Bussiere, 1998) (for reviews, see Chaffin, 2008; Letourneau \& Miner, 2005; Trivits \& Reppucci, 2002). Thus, sex offender registries might not be an effective strategy for reducing recidivism among juvenile sex offenders. In addition, recent research suggests that these laws might actually be decreasing the likelihood that prosecutors will forward juvenile sex offenders' cases for prosecution, particularly younger juveniles with no prior offenses (Letourneau, Bandyopadhyay, Sinha, \& Armstrong, 2009).

Despite this research, sex offender registry legislation has become more and more inclusive of juveniles (Salerno et al., in press). This movement might stem, in part, from politicians and policymakers assuming believing that their constituents support severe reactions to sex offenders, including registry laws. A recent survey of legislators and public officials revealed that although few were confident that current laws would actually decrease sex offenses, nearly all recognized the public demand that "something be done" about such crimes (Sample \& Kadleck, 2008). One legislator remarked, "People are scared for their kids. They want some help. At least we look like we are giving them some" (p. 56). Researcher Chaffin (2008) has remarked that "the sound bite that we should put our kids' safety before the rights of sexual offenders, adult or juvenile, sounds so intuitively correct that it is a guaranteed political winner, even if the policy it promotes is ultimately destructive and fails to deliver the child protection goods" (p. 120). Comments such as these suggest that a "tough on sex crimes" platform would be more popular with the public than a platform based on making sex offender registration laws more lenient. Indeed, politicians who question registry laws have faced trouble: In 2002, the only Iowa House member to vote against a bill to implement housing restrictions for sex offenders was targeted with negative campaign flyers with a photograph depicting a prisoner in an orange jumpsuit looking through a fence at a schoolyard full of children and a tagline asking, "Why does Ed Fallon think it's ok for sex offenders to live near schools?” (Brenton, 2008). Thus, public 
opinion might have a strong impact on politicians' and policymakers' decisions about sex offender legislation.

The public is, in fact, strongly in favor of policies that require adult sex offenders to register (Phillips, 1998) and that notify community members about neighborhood adult sex offenders. For example, Levenson, Brannon, Fortney, and Baker (2007) found that $76 \%$ of community members surveyed believed that all adult sex offenders should be subject to community notification, and Phillips (1998) found that $80 \%$ of survey respondents believed that community notification laws are very important. Other research has also shown high public support for adult registry and community notification laws (Caputo \& Brodsky, 2004; Proctor, Badzinski, \& Johnson, 2002; Redlich, 2001). It is important, however, to test politicians' and policymakers' assumption that such support extends to juvenile sex offenders. If not, policymakers might feel freer to base their decision to support juvenile registry laws on social scientific evidence about the laws' actual effectiveness (or lack thereof) for deterring recidivism and protecting the community.

So, does the public support the application of registry laws to juvenile sex offenders? Although developmental differences generally render juvenile offenders less legally culpable than adult offenders (e.g., Cauffman \& Steinberg, 2000), the 1990s saw increasingly punitive attitudes toward juvenile offenders (Levesque, 1996). Yet public attitudes might be shifting toward treating juveniles more leniently than adult offenders (Scott, Reppucci, Antonishak, \& DeGennaro, 2006), consistent with the original rehabilitative philosophy of the juvenile justice system (for review, see Reppucci, Michel, \& Kostelnik, 2009). Two studies have examined support for the application of registry laws to juveniles. First, Stevenson, Sorenson, Smith, Sekely, and Dzwairo (in press) explored support for registering a 15-year-old boy in a case involving mutually desired oral sex with an underage girl (i.e., statutory rape). Stevenson and colleagues found that, on average, participants supported registration as long as the juvenile's information would not be posted on the Internet, although there was a marginally significant tendency for participants to support more punitive policies when the juvenile and victim 
were of different races (Black versus White) rather than of the same race. Second, Kernsmith, Craun, and Foster (2009) found that $86 \%$ of respondents agreed that a juvenile under the age of 18 who forced someone to have sex should be required to register, but the juvenile was perceived as less worthy of registration than adults who sexually abused children. The confounding of age and offense in this study makes it difficult to isolate the effect of offender age on registry support.

Thus, although prior research suggests that the public might support registration for juveniles who have forced and non-forced sex with a minor, it is not completely clear how support differs for registering juveniles versus adults, or whether this support would extend to less severe offenses. Therefore, in three studies, we examined (a) laypeople's and legal professionals' support for sex offender registration for juveniles versus adults (Study 1) and (b) whether support for registration for juveniles and adults is affected by laypeople's prototypes of sex offenders and their offenses (Study 2). We also tested whether support depends on juvenile offender age and offense severity (Study 3). Across all studies, we investigated the influence of two potential attitudinal mediators of these effects: the perceived threat to community safety posed by offenders (a utilitarian concern) and feelings of moral outrage (a retributive concern).

\section{Study 1}

In Study 1, we explored whether there would be differences in support for applying sex offender registry laws to juveniles versus adults. Support for adult registry laws likely stems from beliefs about the effectiveness of registration and sex offenders' recidivism rates and amenability to treatment. For example, in Levenson and colleagues' (2007) survey, 83\% of community members agreed that community notification is effective in reducing sex offenses, $74 \%$ agreed that adult sex offenders go on to commit other sex offenses, and $68 \%$ agreed that they are much more likely to reoffend than are other criminals. Schiavone and Jeglic (2008) reported that, of those surveyed, 65\% agreed that communities are safer when they know where sex offenders live and $44 \%$ agreed that registration and community notification prevent offending (although 57\% did not believe that Megan's 
Law affects the rate of recidivism among sex offenders). In reality, compared to offenders who commit nonsexual crimes, sex offenders are less likely to commit nonsexual offenses and only slightly more likely to commit another sex offense (U.S. Department of Justice, 2007). Even so, support for registry policies are driven by beliefs in the efficacy of the policies, sex offenders' amenability to be rehabilitated, and feelings of anger and fear at the thought of having a sex offender living in the neighborhood (Redlich, 2001). Further, Caputo and Brodsky (2004) found that individuals who favored community notification were more likely to be fearful about crime in general. Thus, support for adult registry laws probably stems from utilitarian concerns about protecting society from dangerous sex offenders who recidivate at high rates. This is consistent with attribution theory, which suggests that utilitarian concerns to protect society lead to punitive reactions to criminals (e.g., longer sentences, or in this case, more strict registration laws) (Weiner, 2006).

On the one hand, the basis of support for applying registry laws to juveniles might be the same as for applying registry laws to adults. The public might be just as concerned about protecting society from juvenile as adult sex offenders, leading them to support registration equally for juveniles and adults. Sahlstrom and Jeglic (2008) examined attitudes toward juvenile sex offenders ranging in age from 8 to 13 years and found that, on average, participants generally had negative attitudes toward juvenile sex offenders and their potential to rehabilitate, and supported interventions from either the juvenile's parents, the police, or child protective services. On the other hand, the public might be less supportive of registry laws for juveniles than for adults. According to attribution theory, utilitarian concerns may be triggered by stable attributions for a crime (e.g., that an offender is permanently dangerous and likely to recidivate) (Weiner, 2006). In contrast, unstable attributions for a crime (e.g., in this case, that an offender is immature and will grow out of a developmental phase which often involves sexual experimentation) reduce utilitarian desires to protect society, and in turn engender less punitive reactions (e.g., favoring less strict registration laws). To the extent that people recognize the immaturity and unstable behaviors of juveniles relative to adults, people might view juveniles as less 
dangerous and less threatening to public safety and, in turn, support registry laws less for juveniles relative to adults. Thus, we hypothesized that, if age differences in support for registry laws did manifest, they would be driven by perceptions that juveniles are less threatening than adult sex offenders.

There is evidence, however, that individuals rely even more on retributive than utilitarian concerns during justice decision-making (Carlsmith, Darley, \& Robinson, 2002; Darley, Carlsmith, \& Robinson, 2000), and retributive concerns are linked to support for adult sex offender registry laws. Specifically, in Levenson and colleagues' (2007) survey, 73\% of participants indicated that they "would support these policies even if there is no scientific evidence showing that they reduce sexual abuse." Similarly, Schiavone and Jeglic (2008) found that $20 \%$ believed that even offenders who pose no risk should be subjected to registration and community notification policies.

Registry laws might fulfill a psychological need to punish wrongdoers for their transgressions, which might result, in part, from people's basic drive to protect their beliefs about what is right and wrong (Skitka, 2002; Skitka \& Mullen, 2002; Skitka, Bauman, \& Mullen, 2004). The term moral outrage is used to describe negative affective, cognitive, and behavioral reactions to violations of one's moral norms (Skitka et al., 2004). To the extent that the public attributes juveniles' sex offenses to immaturity or normative adolescent sexual experimentation, they might be less morally outraged at juvenile sex offenders than adult sex offenders. Thus, we predicted that participants would feel less moral outrage toward juvenile compared to adult sex offenders, and, in turn, be less supportive of registry laws for juveniles than for adults.

We were also interested in identifying differential support for registry laws among various groups of people. We were first interested in community opinion. Although creation of laws may be determined by politicians' and policymakers' perceptions of community opinion, laws are implemented on a daily basis by other legal players such as attorneys. Redlich (2001) found no significant differences between community members and law students in terms of support for 
community notification, beliefs about the effectiveness of such policies, beliefs about sex offender rehabilitation, or feelings of anger or fear toward sex offenders. Yet attorneys' support for the application of registry laws to juvenile sex offenders might vary depending on their specific professional roles and their experiences with juvenile sex offenders, which would not yet be developed in law students. For example, experienced prosecutors, who focus on bringing perpetrators to justice, are likely to support registry laws strongly for both juvenile and adult sex offenders. That is, because it is their job to uphold these laws, they might be more likely to be loyal to the letter of the law and support these laws for everyone. In contrast, attorneys with family law interests, who are more likely than prosecutors to work with juveniles in an advocacy (rather than oppositional) role, might be less supportive of registration for juvenile than for adult sex offenders. Therefore, we predicted that community members would be less supportive of registration for juveniles than adults (perceiving juveniles to be less threatening and less morally offensive), whereas prosecuting attorneys would not be affected by offender age. We expected that family law attorneys would be the most affected by offender age, exhibiting the largest difference in support for registry laws for juveniles as compared to adults, moral outrage, and perceptions of threat. Finally, we also surveyed a sample of college undergraduates, because determining the generalizability of results obtained from student samples is a methodological issue of importance to the field of psychology and law. We predicted that our student and community samples would be similar, as is the case in studies comparing mock jury decision making in student and community samples (Bornstein, 1999).

\section{Method}

Study 1 conformed to a 2 (offender age: juvenile, adult) X 4 (sample: community members, undergraduates, prosecuting attorneys, family law attorneys) between-subjects experimental design.

\section{Participants}

Overall, there were 472 participants from four samples: (a) undergraduates from the University of Illinois at Chicago (UIC); (b) prosecuting attorneys recruited at a continuing education conference; 
(c) family law attorneys recruited during a continuing education conference; and (d) laypeople recruited in the community. We dropped an additional 8 participants who were under 18 years old. Only undergraduates were compensated (through course credit) for participating. See Table 1 for sample descriptive characteristics (i.e., gender, age, and ethnicity) and the procedure section for more details about the samples and their recruitment.

\section{Materials}

A questionnaire assessed participants' support for registry laws and perceptions of sex

offenders. The questionnaire instructed participants as follows:

Adults found guilty of a sex offense must be listed on a public sex offender registry. In various states, this registry includes information such as name, social security number, age, race, gender, birth date, physical description, address, place of employment, details about the offense(s), fingerprints, a photo, a blood sample, and a hair sample. This information is available to the public upon request, sometimes by being posted on the Internet. In some cases, the police directly notify the people who live in the same area as the registered sex offender. Sex offenders are required to register anywhere from a few years to their entire life, depending on the state.

Then the questionnaire stated that the researchers were "interested in your thoughts about applying these registration laws to," depending on offender age condition, either (a) "juveniles (16 years old or younger) who have been adjudicated (found guilty in juvenile court) or convicted as sex offenders" or (b) "adults (17 years old or older) who have been convicted as sex offenders." The questionnaire included each of the measures described below in the order listed.

Support for registry laws. Participants were asked, "In your opinion, what is generally the most appropriate outcome for [adjudicated or convicted juvenile sex offenders/convicted adult sex offenders]?" All participants were given the first three response options: (a) "[juvenile/adult] sex offenders should never be required to register at all with law enforcement in their communities;" (b) "[juvenile/adult] sex offenders should be required to register, but their information should never be posted on the Internet;" and (c) "[juvenile/adult] sex offenders should be required to register and their information should be publicly posted on the Internet beginning at the time they are 
[adjudicated/convicted]." Participants who read about juvenile sex offenders were also given the option, "juvenile sex offenders should be required to register, but their information should not be posted on the Internet until they turn 18, at which time their information should be publicly posted on the Internet" - an option in many states. To conduct direct comparisons across offender age conditions, the last two response options for the juvenile version were collapsed, making the registry support dependent measure an ordinal variable composed of 3 levels for all participants: no support for the registry, support for a registry that is not posted online, or support for an online registry.

Perceived Threat Scale. The Perceived Threat Scale comprised 4 items modeled after those used in prior research about juvenile offenders in general (Haegerich \& Bottoms, 2004; Vidal \& Skeem, 2007) and sex offenders specifically (Proeve \& Howells, 2006). The 5-point response scales ranged from -2 (strongly disagree) to +2 (strongly agree), and were transformed for analyses to 1 (strongly disagree) to 5 (strongly agree). The items assessed the extent to which participants agreed that (a) “[adult/juvenile] sex offenders pose a danger to society," (b) “[adult/juvenile] sex offenders are at high risk for reoffending," (c) “[adult/juvenile] sex offenders are cold and calculating 'superpredators,"” and (d) “[adult/juvenile] sex offenders can be rehabilitated (reformed)." The last item was reverse-scored. The scale had good internal reliability generally (Cronbach's $\alpha=.70$, mean inter-item correlation $=.38)$ and within each subsample $(\alpha$ s ranging from .55 to .76 and mean interitem correlations ranging from .23 to .45$)$.

Moral Outrage Scale. For the community member sample, the questionnaire included a 4-item Moral Outrage Scale modified from measures used by Skitka and colleagues (2004) and Wiley and Bottoms (2009): (a) "I feel a compelling need to punish [adult/juvenile] sex offenders," (b) "I feel a desire to hurt [adult/juvenile] sex offenders," (c) "I believe [adult/juvenile] sex offenders are evil to the core," and (d) "I feel morally outraged by what [adult/juvenile] sex offenders did to their alleged victims." Responses were given on 6-point scales ranging from -3 (strongly disagree) to +3 (strongly agree) with no midpoint. Values were transformed to create a scale ranging from 1 (strongly disagree) 
to 6 (strongly agree) with good internal reliability $(\alpha=.77$, mean inter-item correlation $=.46)$.

Demographic information. Participants were asked to provide their age, gender, and ethnicity. Prosecuting attorneys and family law attorneys were also asked the open-ended question, "What kind of law do you practice?"

\section{Procedure}

Undergraduates completed our measures along with various unrelated questionnaires submitted by other researchers during a mass-testing session. Community members were approached in various public settings in the Chicago area (i.e., mainly trains, but also airports, malls, etc.). Prosecutors were invited to complete the measures just prior to attending a continuing education class about a computer software package. Attorneys with family law interests were invited to participate at an annual state meeting during either a (a) continuing education class on family law, (b) a business meeting of a child law organization, or (c) a business meeting of criminal law private practitioners. (In the latter group, only those attorneys who reported that they practiced family law were included in the sample.) Thus, although not all of these attorneys necessarily specialized in family law, their behavior or selfdescription indicated interest in the topic. For the purposes of our discussion herein, we have selected what we believe to be a parsimonious label for this group: "family law attorneys." This sample provides an important comparison for the prosecutor sample because such participants are more likely to come into contact with children in an advocacy role, as compared to prosecutors who are more likely to come into contact with children in an oppositional role. All participants were (a) told that their participation was voluntary and anonymous, (b) randomly assigned to offender age condition, (c) thanked for their participation, and (d) treated according to the guidelines of the UIC Institutional Review Board.

\section{Results}

We used ordinal logistic regression to test the effect of offender age (juvenile versus adult) and sample (community members, undergraduates, prosecuting attorneys, and family law attorneys) on 
participants' likelihood of supporting more punitive registry laws. We used multiple linear regressions to test the effect of offender age and sample on continuous outcomes (i.e., perceived threat and moral outrage). In all analyses, offender age was dummy coded with juveniles as the reference group. The effect of sample was represented by a set of 3 dummy codes with community members as the reference group, reflecting comparisons between community members and (a) undergraduates, (b) prosecuting attorneys, and (c) family law attorneys. All possible two-way interactions were entered into the models predicting support for registry laws and perceived threat to determine whether offender age had the same influence on these variables for community members as compared to each of the other three groups separately. The main effect of sample and the interaction effects for offender age and sample were omitted from the model predicting moral outrage because only community members completed that measure. The overall model was significant for support for registry laws, $\chi^{2}(7, N=456)=37.74, p$ $<.001$, Pseudo $R^{2}=.06$ and perceived threat, $F(7,470)=17.40, p<.001, R^{2}=.20$. The model for moral outrage was also significant, $F(1,216)=13.47, p<.001, R^{2}=.06$. Next, in separate sections, we present the main effects and two-way interactions revealed by these analyses. Finally, we present results from mediation analyses testing whether perceived threat (i.e., utilitarian concerns) and moral outrage (i.e., retributive concerns) mediate significant effects revealed by the primary analyses. Offender Age Main Effects

Overall, $95 \%$ of participants thought that some form of registration was generally the most appropriate outcome for sex offenders. (See Table 2.) Contrary to hypotheses, there was no significant effect of offender age on support for registry laws, $\mathrm{OR}=1.51, z=1.42, n s$ - even though, as expected, participants perceived that adult sex offenders pose more of a threat to public safety than do juvenile sex offenders, $B=.48, t(462)=5.46, p<.001$ (see Table 2 ). Community members (the only sample to complete the moral outrage measure) were significantly more morally outraged by adult than juvenile sex offenders $(M=3.94, S D=1.05$ vs. $M=3.46, S D=1.03), B=.52, t(214)=3.67, p<.001$. 
Sample Main Effects

Overall, family law attorneys were the least likely to support harsher registry laws, followed by community members and prosecutors (who did not differ from each other), then by undergraduates (who differed from community members but not prosecutors). Family law attorneys perceived offenders to pose the least threat, followed by undergraduates and community members (who did not differ from each other), then by prosecutors. Specifically, compared to community members, prosecutors did not differ significantly in their support for registry laws, OR $=2.25, z=1.39, n s$, but did perceive sex offenders as more threatening, $B=.61, t(462)=3.84, p<.001$. Compared to community members, family law attorneys were significantly less likely to support harsher registry laws, $\mathrm{OR}=.12, z=-3.79, p<.001$, and perceived sex offenders as less threatening, $B=-.84, t(462)=-$ $4.81, p<.001$. Contrary to our hypothesis, undergraduates were more likely than community members to support harsher registry laws, $\mathrm{OR}=1.96, z=2.00, p=.05$, but, as expected, did not differ from community members in terms of perceived threat, $B=-.06, t(462)=-.64, n s$.

Additional post hoc regressions were performed with alternate reference groups to test for differences between family law attorneys, prosecuting attorneys, and undergraduates. Undergraduates and prosecutors did not differ from each other in terms of support for registry laws, $\mathrm{OR}=1.54, \mathrm{z}=.72$, $n s$, although prosecutors did perceive sex offenders as a greater threat than did undergraduates, $B=.73$, $t(462)=4.47, p<.001$. Compared to family law attorneys, prosecutors and undergraduates (a) were significantly more likely to support harsher registry laws, $\mathrm{OR}=16.51, z=4.03, p<.001$, and $\mathrm{OR}=$ $14.40, z=5.25, p<.001$, and (b) perceived sex offenders as significantly more threatening to public safety, $B=1.36, t(462)=6.97, p<.001$, and $B=.69, t(462)=4.57, p<.001$.

\section{Offender Age X Sample Interactions}

For support for registry laws, offender age significantly interacted with the dummy code contrasting community members and family law attorneys, $\mathrm{OR}=5.05, z=2.20, p<.05$. Examination of simple slopes revealed that family law attorneys were significantly more likely to support harsher 
registry laws for adult than for juvenile sex offenders, $\mathrm{OR}=7.61, z=2.98, p<.01$, but offender age did not significantly affect community members' registry support, $\mathrm{OR}=1.51, z=1.42, n s$.

This interaction was also significant for the Perceived Threat Scale, in the predicted direction, $B=.51, t(462)=2.17, p<.05$. Examination of simple slopes revealed that both community members and family law attorneys perceived adult (versus juvenile) sex offenders as more threatening, $B=.48$, $t(462)=5.46, p<.001$, and $B=.98, t(462)=4.56, p<.001$, respectively. As indicated by the larger path coefficients, however, the effect of offender age on perceptions of threat was larger for family law attorneys than for community members. There were no other significant offender age X sample interaction effects, $\mathrm{OR}=.58, z=-1.13, n s$, and all $B \mathrm{~s} \leq|.19|, t(462) \mathrm{s} \leq|1.42|, n s$. (Note that we could not test whether offender age interacted with the dummy code that compared community members to prosecuting attorneys to influence support for registry laws because all prosecuting attorneys responded that sex offenders should be required to register online.)

\section{Understanding the Effect of Offender Age on Family Law Attorneys' Support for Registry Laws}

Because there was a significant effect of offender age on registry support only for family law attorneys, we included only that sample in our meditation analyses testing the hypothesis that perceived threat (i.e., utilitarian concerns) drives age differences in registry support. (We did not test our meditation hypothesis concerning moral outrage because it was only measured in the community sample, for which there was no significant offender age effect.) According to Baron and Kenny (1986), to establish mediation (a) the independent variable must predict the dependent variable, (b) the independent variable must predict the proposed mediator, (c) the mediator must predict the dependent variable after controlling for the effect of the independent variable, and (d) adding the mediator to the model must either reduce (partial mediation) or eliminate (full mediation) the effect of the independent variable on the dependent variable. We found evidence for full mediation. Specifically, consistent with our prior analyses reported earlier, family law attorneys were over 7 times more likely to support harsher registry laws for adult than juvenile sex offenders, $\mathrm{OR}=7.63, z=2.77, p<.01$. They also 
perceived adults as more threatening than juveniles, $B=.99, t(38)=4.82, p<.001$. When offender age and perceived threat were simultaneously entered into an ordinal logistic regression predicting family law attorneys' support for registry laws, the odds ratio for offender age dropped from 7.63 to 1.60 , which was no longer significant, $z=.54, p=.59$. Perceived threat did, however, still significantly predict support for the registry, $\mathrm{OR}=10.29, z=2.93, p<.01$. Thus, family law attorneys perceive juvenile sex offenders to be significantly less threatening to public safety than adult sex offenders, which in turn leads them to be less supportive of registry laws for juveniles as compared to adults.

\section{Study 1 Summary and Discussion}

Overall, we found high levels of support for registry laws for adult sex offenders, as expected, but also for juveniles. This was true even though participants (at least community members) were less morally outraged when considering juvenile versus adult offenders, and even though participants correctly perceived juvenile sex offenders as less threatening to public safety than adults. Although Scott and colleagues (2006) have suggested that public attitudes toward juvenile offenders are becoming less punitive than in the past, Study 1 results suggest that this might not be the case with regard to juvenile sex offenders.

Even so, family law attorneys were sensitive to offender age, supporting less harsh laws for juveniles than adults, which was explained by their perceptions that juvenile versus adult sex offenders pose less of a threat to public safety (an effect that was stronger for family law attorneys than for community members). Why would there not be an age effect for the other samples? Family law attorneys likely serve in an advocacy role for juveniles involved in the legal system. Thus, when thinking of juvenile sex offenders in the abstract (as we asked participants in Study 1 to do), family law attorneys might imagine less severe types of offenders than do others. Laypersons and prosecutors might be more likely to envision severe sex offender stereotypes. In fact, research suggests that people often have a violent prototype of sex offenders (Finkel \& Groscup, 1997; Krahé, 1991), envisioning an offender who forces unwilling individuals to engage in sexual acts (Quinn, Forsyth, \& Mullen-Quinn, 
2004). Prototypes and stereotypes have been shown to influence legal decision making in other types of cases involving juvenile offenders. For instance, Haegerich and Bottoms (2004) demonstrated that the type of stereotype mock jurors endorsed about juvenile offenders accused of murder (i.e., immature "wayward youths" versus cold and calculating "superpredators") influenced their decisions in a trial. Thus, the accessibility or endorsement of either the less severe or more severe prototype for juvenile sex offenders might trump the implications of their age and explain prosecutors', community members', and undergraduates' equal support for registry laws for juvenile and adult offenders. In other words, people might support the application of registry laws to juvenile sex offenders because most people envision a severe sex offender prototype even when asked to think about a juvenile sex offender.

Severe prototypes of juvenile sex offenders are not necessarily accurate representations of all juvenile sex offenders. Although some juvenile sex offenders surely fit a more severe prototype, forcible rapes accounted for only 15\% of sex crimes committed by persons under age 18 in 2007 (U.S. Department of Justice, 2007). In fact, juveniles are sometimes placed on sex offender registries for less severe offenses such as exposing themselves in classrooms ("No Easy Answers," 2007) and engaging in consensual sexual relations with same-aged peers ("No Easy Answers," 2007; e.g., Wilson v. State, 2006). Family law attorneys might have been more likely to envision these less severe prototypes than all other groups, which would explain why they were the only group to support the registry for juveniles less than adults.

Study 2

Prior research has demonstrated that people naturally have crime prototypes and prototypes influence their verdict decisions (Smith, 1991). Yet prototypes are not always accurate-when asked about crimes in the abstract, people base their punishment preferences on overly severe crime stereotypes (Stalans \& Diamond, 1990) and biased recall of severe crimes (Stalans, 1993). Thus, in Study 2, we tested whether the public holds a generally severe prototype of sex offenders (regardless 
of offender age), and whether that prototype influences support for registry laws. We asked participants to complete the same measures from Study 1, but afterward asked them directly what type of crime and offender they imagined while responding to the measures. We then examined whether participants who envision more severe prototypes support the registry more than participants who envision less severe prototypes. We also tested whether perceived threat (i.e., utilitarian concerns) and/or moral outrage (i.e., retributive concerns) would mediate the effect of prototypes on support for registry laws. We predicted that participants would (a) support the registry equally for juvenile and adult sex offenders (as we found in Study 1), (b) be more likely to have more severe than less severe prototypes regardless of offender age, and (c) exhibit some variation in prototype severity, and that those who naturally envisioned more (versus less) severe sex offender prototypes would be more likely to support harsher registry laws, perceive greater threat, and be more morally outraged at sex offenders. Finally, we predicted that the effect of prototypes on registry support would be mediated by both perceived threat (i.e., utilitarian concerns) and moral outrage (i.e., retributive concerns). We tested these theories in a preliminary manner in Study 2 with an undergraduate sample, then tested them in a more controlled manner in Study 3 with another community sample. We had no reason to think these underlying psychological mechanisms would differ for attorney samples, and so we pursued no further issues related to sample. In other words, the samples are thought to differ in where they fall on the continuum of prototype severity, but the underlying psychological mechanism (i.e., more severe prototypes lead to more support for registry laws) is predicted to be the same for all samples.

\section{Method}

Study 2 conformed to a 2 (offender age: juvenile, adult) X 2 (sex offender prototype: more severe, less severe) between-subjects design.

\section{Participants}

Overall, 104 undergraduates from UIC received course credit for participating. See Table 1 for sample descriptive characteristics. 


\section{Materials}

Materials included the same juvenile and adult versions of the questionnaire described in Study 1 , which measured support for registry laws, perceived threat $(\alpha=.73$, mean inter-item correlation $=$ $.41)$, and moral outrage $(\alpha=.81$, mean inter-item correlation $=.53)$, with the exception that two openended questions were added at the end: (a) "Now, we would like you to think back to what type of sex offender you were envisioning while you were answering the previous questions about sex offenders. What kind of person were you thinking of? What kind of person did you have in mind? Describe anything about the person you remember thinking while you were answering the questions_any characteristics"; and (b) "What would you consider the 'typical' sex offender crime? In other words, what type of crime were you envisioning when you answered the questions?" Participants were given space to write their response, but they could also check a box to indicate that they "can't write anything because I don't remember thinking about anything in particular."

As in Study 1, the questionnaire included questions about participant age, gender, and ethnicity.

\section{Procedure}

Participants were randomly assigned to offender age condition, completed the questionnaire alone or in mixed-gender groups of 2 to 10 in the laboratory, then were debriefed and thanked.

We coded open-ended responses for evidence of either more severe or less severe prototypes of sex offenders and the offenses they commit. Participants were categorized as having a more severe prototype if they made references to forced sex acts (e.g., rape, sexual assault, child sexual abuse). Participants were categorized as having a less severe prototype if their responses were either (a) specifically about less severe, nonviolent offenses (e.g., "An 18-year-old who has consensual sex with a 16- to 17-year-old") or (b) sympathetic or observant of situational factors such as immaturity that might have contributed to the crime and absolve them of criminal intent (e.g., "A white girl regretting having sex with an older guy so she then goes to the police"; "Someone who doesn't really understand sex but whose hormones are 'bouncing' all over the place. Anyone under 16 doesn't fully understand 
the meaning of sex"). To be conservative, we coded participants as "neither" if (a) their responses did not clearly fit into the more or less severe categories or (b) they did not answer the question. These participants were dropped from analyses. $^{2}$

Two independent raters coded $60 \%$ of participants' responses $(n=62)$ and were reliable on each of the three individual codes (proportions of agreement $\geq .77, M$ across categories $=.86$ ). Disagreements were resolved by discussion. One rater coded the remaining data. Of the 104 participants, $28 \%$ were not included in the analyses because (a) they endorsed a combination of more severe and less severe prototypes of sex offenders and/or the offenses they commit $(n=6)$ or $(b)$ they fell into the "neither" category $(n=24)$. Thus, analyses included the $78 \%(n=74)$ of participants who naturally envisioned either a more or less severe prototype while completing the measures.

\section{Results}

First, we tested (a) whether participants were more likely to envision a more severe or less severe prototype, and (b) whether this likelihood depended upon offender age (juvenile versus adult), using chi-square analyses. Next, we tested the effect of offender age and sex offender prototype using the same analytic strategy as Study 1, except that we included sex offender prototype instead of sample (with less severe prototype as the reference group), and the corresponding interaction between offender age and sex offender prototype. This overall model was significant for support for registry laws, $\chi^{2}(3$, $N=74)=8.73, p<.05$, Pseudo $R^{2}=.08$, perceived threat, $F(3,70)=14.22, p<.001, R^{2}=.38$, and moral outrage, $F(3,70)=9.57, p<.001, R^{2}=.29$. As in Study 1 , we organize our presentation of the significant effects revealed by these models as a function of independent variable, followed by mediation analyses testing whether perceived threat and moral outrage mediated significant effects revealed in the primary analyses.

\section{Prototypes of Sex Offenders}

As expected, significantly more participants (76\%) envisioned a more severe prototype than a less severe prototype $(24 \%), \chi^{2}(1, N=74)=19.51, p<.001$. This was not significantly affected by 
offender age, with $55 \%$ of participants who read about adult offenders envisioning a more severe prototype and $45 \%$ of participants who read about juvenile offenders envisioning a more severe prototype, $\chi^{2}(1, N=74)=1.48, n s$.

In line with our predictions, participants who envisioned a more severe as compared to a less severe prototype (a) were more than 4 times more likely to support registry laws, $\mathrm{OR}=4.15, z=1.93$, $p=.05$ (see Table 3); (b) rated sex offenders as a greater threat $(M=3.50, S D=.62$ vs. $M=2.67, S D=$ $.74), B=.99, t(70)=4.61, p<.001 ;$ and $(c)$ were more morally outraged $(M=3.92, S D=.97$ vs. $M=$ 3.03, $S D=1.13), B=1.14, t(70)=3.43, p<.01$.

\section{Offender Age Main Effects}

As in Study 1, there was strong support for registry laws: Overall, 95\% of participants thought that some form of registration was generally the most appropriate outcome for sex offenders. (See Table 3 for registry support as a function of offender age and prototype.) Also as in Study 1, support for registry laws was not significantly influenced by offender age, $\mathrm{OR}=.55, z=-.64, n s$, even though — as expected — compared to juvenile sex offenders, participants perceived adult sex offenders as significantly more threatening $(M=3.07, S D=.77$ vs. $M=3.58, S D=.58), B=.95, t(70)=3.31, p$ $=.001$, and were more morally outraged by adult sex offenders $(M=3.23, S D=.98$ vs. $M=4.09, S D=$ $.95), B=1.47, t(70)=3.30, p<.01$, respectively.

\section{Prototypes of Sex Offenders X Offender Age Interactions}

The interaction between prototypes of sex offenders and offender age was not statistically significant for support for registry laws, $\mathrm{OR}=1.59, z=.41, n s$, perceived threat, $B=-.58, t(70)=-$ $1.77, p=.08$, nor moral outrage, $B=-90, t(70)=-1.77, p=.08$.

\section{Understanding the Effect of Prototype on Support for Registry Laws}

Next, we tested whether the effect of sex offender prototype on support for registry laws was mediated by perceived threat (i.e., utilitarian concerns) and moral outrage (i.e., retributive concerns). As presented earlier, participants who envisioned a more (versus less) severe prototype were more 
likely to support harsher registry laws, $\mathrm{OR}=4.73, z=2.82, \mathrm{p}<.01$, perceived sex offenders as more threatening, $B=.83, t(72)=4.69, p<.001$, and were more morally outraged, $B=.89, t(74)=3.24, p<$ .01 . Yet when prototype, perceived threat, and moral outrage were simultaneously entered as predictors of support for registry laws, the effect of prototype was no longer significant, $\mathrm{OR}=2.06, z=$ $1.13, p=.26$, indicating full mediation. Moral outrage was not a significant predictor of support for registry laws, $\mathrm{OR}=.85, z=-.48, n s$, but perceived threat was, $\mathrm{OR}=4.00, z=2.43, p<.05$. Thus, participants who envisioned a more (versus less) severe prototype perceived sex offenders to be a greater threat, which in turn led to greater support for registry laws.

\section{Study 2 Summary and Discussion}

We replicated findings from Study 1: The public, in this case undergraduates, did not reliably distinguish between juveniles and adults in their support for registry laws, even though they perceived juveniles as less of a threat to public safety and felt less morally outraged toward juveniles. Further, our results support our theory that support for registry laws is unaffected by offender age because people generally envision a severe prototype when asked to imagine a sex offender, regardless of the offender's age. Even so, there was some individual variation in the severity of prototypes, and participants who envisioned a more severe prototype were more likely to support registry laws than participants who envisioned a less severe prototype. This finding is consistent with prior work on people's punishment preferences for nonsexual offenses (Stalans, 1993; Stalans \& Diamond, 1990). In our study, this effect was explained by utilitarian concerns: When people envision a more severe prototype, they perceive sex offenders to be a greater threat to society, which in turn leads to greater likelihood of supporting harsher registry laws. Thus, when members of the public are asked about their support for juvenile registry laws, they are likely reporting their level of support for registering juveniles who commit severe offenses. If faced with a specific example of a less severe offender, would they support registry laws less? 
Study 3

Research has shown that the American public prefers more punitive policies in the abstract or in general compared to when those policies are considered in specific cases. For example, when asked about laws that hold parents responsible for their children's crimes globally (e.g., "Parents are to blame when their child breaks the law") versus in response to a vignette describing a specific case (e.g., "Joseph's parents are to blame for the crime he committed"), participants perceived the parents as more blameworthy and responsible (but not more deserving of punishment) (Brank, Hays, \& Weisz, 2006). Differences in global versus specific attitudes have also been found in studies examining support for giving juveniles the death penalty (Moon, Sundt, Cullen, \& Wright, 2000) and sentencing policies for adult offenders (e.g., Applegate, Cullen, Turner, \& Sundt, 1996). Zamble and Kalm (1990) found that Canadian public opinion about sentencing was punitive when assessed in the abstract, but when presented with specific cases, participants were less punitive toward (a) offenders who committed less severe (e.g., theft, robbery) versus more severe crimes (e.g., breaking and entering, assault and robbery) and (b) younger (17- to 19-year-old) versus older (35- to 38-year-old) offenders. Although no studies have explored differences in global versus specific attitudes toward sex offenders or registry laws, prior research suggests that participants who are asked about specific cases will (a) support less harsh registry laws compared to participants who are asked about support in the abstract (as in Study 1 and Study 2), and (b) support less harsh registry laws for juveniles who are younger (versus older) and commit less (versus more) severe sex offenses.

Thus, we conducted Study 3 as a more controlled test of the theories we addressed in Study 2 and to determine whether support for registry laws depends on specific case factors: offense severity and age of juvenile offender. Specifically, we asked laypeople (i.e., community members and undergraduates) to complete the questionnaire and randomly assigned them to envision a juvenile who had committed either a (a) more severe offense (i.e., rape) or (b) less severe offense (i.e., child pornography, sexual harassment, or consensual statutory rape). We predicted that the public's support 
for registry laws would depend on offense severity — that the overall support we observed in Study 1 would not apply to all juvenile cases. Based on results from Study 2, we predicted that those who read about a more severe, as opposed to a less severe offense, would (a) be more likely to support more punitive registry laws, (b) perceive the sex offender as more threatening to public safety, and (c) be more morally outraged.

We also expected that the public's support for registry laws would depend on juvenile offender age. One reason there were no differences in laypeople's prototypes and support for registry laws for juveniles as compared to adults might be because people assume that all juvenile sex offenders are older teenagers, whom they might see as more similar to adults. We manipulated the age of the juvenile (12 versus 16 years old), expecting that participants would be less supportive of registry laws, perceive less threat, and be less morally outraged when reading about a younger rather than an older juvenile, for similar reasons used to justify our (unsupported) predictions about age differences in Study 1 .

Finally, we also explored the degree to which perceived threat (i.e., utilitarian concerns) and moral outrage (i.e., retributive concerns) mediated the predicted effects of offense severity and juvenile offender age on laypeople's support for registry laws.

\section{Method}

Study 3 conformed to a 2 (juvenile offender age: 12 years old, 16 years old) X 2 (offense severity: more severe, less severe) X 2 (sample: community members, undergraduates) betweensubjects experimental design.

\section{Participants}

Overall, there were 546 participants from two samples: (a) undergraduates from UIC, and (b) laypeople recruited in the community. We dropped an additional 4 participants who were under 18 years old. All volunteered; undergraduates (only) also received course credit in return for participating. See Table 1 for sample descriptive characteristics and the procedures section for more details about the 
samples and their recruitment.

\section{Materials}

Materials included a version of the questionnaire described in Study 1, with some modifications. After the same first paragraph that delivered basic information about sex offender registration, a second brief paragraph was added to describe a specific juvenile sex offender, including the experimental manipulations of offender age and offense severity. Specifically, in all conditions, the juvenile was described as a boy who had been adjudicated delinquent in juvenile court for committing a sex offense. He was described as either 12 years old or 16 years old and as having committed either a more severe offense (attacked and raped a girl in a park) or one of three less severe offenses: (a) got caught looking at naked pictures of his underage girlfriend that she had emailed to him (child pornography), (b) ran through school hallways grabbing girls' buttocks (sexual harassment), or (c) participated in and videotaped mutually desired oral sex with an underage girl (statutory rape). Each of the latter three offenses was based on an actual case in which sex offender registration was a possible outcome (e.g., Goldsmith, 2007; Stockinger, 2009; Wilson v. State, 2006). Thus, there were 8 experimental versions of the questionnaire, created by fully crossing offender age and offense severity. For example, in the 16-year-old child pornography vignette, participants read:

While David (a 16-year-old male) was checking his email in the school library, he received a message that contained naked pictures of his girlfriend. As he was viewing the pictures, a librarian walked by, noticed, and sent him to the principal's office. After the school officials investigated, they discovered that the girl in the pictures was underage. David was adjudicated for possession of child pornography.

The other three vignettes were similar in length and level of detail.

Instead of asking about sex offenders in the abstract, the questionnaire items assessing support for registry laws, perceived threat, and moral outrage were tailored to ask specifically about the juvenile described in the vignette. After changing the items in this way, the Perceived Threat Scale was not as reliable $(\alpha=.64$, mean inter-item correlation $=.30)$ as it was in Study 1 and Study 2. Dropping the item that stated that the juvenile "can be rehabilitated (reformed)," however, improved internal 
reliability across all participants $(\alpha=.81$, mean inter-item correlation $=.60)$, and in each subsample (community members: $\alpha=.83$, mean inter-item correlation $=.63$; and undergraduates: $\alpha=.78$, mean inter-item correlation $=.56$ ). Because we had tested hypotheses about moral outrage with community members in Study 1, we again included this scale for the community members. The Moral Outrage Scale had good internal reliability $(\alpha=.77$, mean inter-item correlation $=.49)$. Finally, the questionnaire included the same measures of age, gender, and ethnicity.

\section{Procedure}

Community members were recruited using the same procedures described in Study 1. Seventynine percent of the undergraduates participated in the type of mass-testing session described in Study 1, the remainder completed the questionnaire by coming to the laboratory alone or in groups of up to 24. Participants were randomly assigned to experimental conditions. Participants were asked to complete all questions in response to the specific offense described in the vignette. Participants completed the adapted questionnaire and were debriefed and thanked.

\section{Results}

We used a similar analytic strategy as in Study 1 and Study 2. In all analyses, juvenile offender age (12 versus 16 years old), offense severity (pornography, harassment, statutory rape, versus rape), and sample (undergraduates versus community members) were dummy coded. The 12-year-old offender and undergraduates were the reference groups for the offender age and sample variables, respectively. The effect of offense severity was represented by a set of 3 dummy codes with rape as the reference group, reflecting the effect of rape versus (a) pornography, (b) harassment, and (c) statutory rape. We also entered all possible two-way interactions.

These preliminary analyses revealed that participants were significantly more supportive of registry laws when the juvenile was described as committing a more severe offense compared to when the juvenile was described as committing any of the three less severe offenses, all ORs $\geq .09, z \mathrm{~s} \geq$ $|3.79|, p s<.001$. Additional post hoc regressions were performed with alternate reference groups to 
test for differences between the child pornography, harassment, and statutory rape cases. There were no significant differences across the three less severe cases in support for registry laws, all ORs $\leq 2.63$, $z \mathrm{~s} \leq 1.81, p \mathrm{~s} \geq .07$, perceived threat, all $B \mathrm{~s} \leq .21, t(525) \mathrm{s} \leq 1.73, p \mathrm{~s} \geq .09$, nor moral outrage, all $B \mathrm{~s} \leq$ .40 , all $t(153) \mathrm{s}<1.36$, all $n s$. Given these results and the lack of a compelling theoretical rationale for examining each of the four offense types separately, we collapsed across the three less severe offenses to create a dichotomous offense severity variable (more severe versus less severe).

We conducted the analysis described above again, substituting the set of dummy codes representing the offense severity variable with one dichotomous less versus more severe offense type variable, with less severe offenses as the reference group. We also substituted the original four-level offense type interactions with the dichotomous offense type interactions. The model was significant for support for registry laws, $\chi^{2}(7, N=539)=140.20, p<.001$, Pseudo $R^{2}=.13$, and perceived threat, $F(6,534)=44.88, p<.001, R^{2}=.34$. The model for moral outrage that included only the offender age variable was also significant, $F(3,157)=12.39, p<.001, R^{2}=.19$.

Sample had only one significant main effect (and was involved in no significant interactions): Community members perceived sex offenders as significantly more threatening than did undergraduates, $B=.23, t(534)=2.03, p<.05$.

\section{Juvenile Offender Age Main Effects}

As predicted, participants were two times more likely to support registry laws for a 16-year-old than for a 12-year-old juvenile sex offender, $\mathrm{OR}=2.17, z=3.42, p<.01$. (See Table 3 for registry support as a function of juvenile offender age and offense severity.) Contrary to our predictions, however, there were no significant effects of age on perceptions of threat $(M=2.20, S D=.94$ vs. $M=$ $2.24, S D=1.00), B=.06, t(534)=.73, n s$, nor feelings of moral outrage $(M=2.32, S D=1.04$ vs. $M=$ 2.22, $S D=1.09), B=-.02, t(157)=-.12, n s$, for younger versus older offenders respectively.

\section{Offense Severity Main Effects}

Compared to participants who read about a juvenile who committed a less severe offense, those 
who read about a juvenile adjudicated delinquent of a more severe offense (a) were over twenty times more likely to support harsher registry laws, $\mathrm{OR}=24.13, z=7.26, p<.000$ (see Table 3), (b) perceived significantly greater threat, $(M=1.99, S D=.80$ vs. $M=3.53, S D=.79), B=1.51, t(541)=$ $9.21, p<.001$, and (c) were significantly more morally outraged $(M=2.00, S D=.91$ vs. $M=3.05, S D$ $=1.11), B=1.26, t(161)=4.97, p<.001$.

Juvenile Offender Age X Offense Severity Interactions

The interaction between juvenile offender age and offense severity was not significant for support for registry laws, OR $=.99, z=-.03, n s$, perceived threat, $B=-.19, t(541)=-.97, n s$, nor moral outrage, $B=-.41, t(161)=-1.17, n s$.

\section{Understanding the Effect of Offense Severity on Support for Registry Laws}

We tested whether perceived threat (i.e., utilitarian concerns) and moral outrage (i.e., retributive concerns) mediated the effect of offense severity on support for registry laws. Because neither mediator was affected by offender age, we did not test for possible mediation of the effects of offender age on support for the registry. First, we tested a multiple mediator model (i.e., perceived threat and moral outrage) for community members, because only they completed the moral outrage scale. Next, we tested a single mediator model (i.e., perceived threat) for the undergraduate sample.

Multiple mediator model for community members. Consistent with results already presented, a series of regressions confirmed that community members were significantly more likely to support harsher registry laws for offenders who committed more severe as compared to less severe sex offenses, $\mathrm{OR}=11.81, z=6.33, p<.001$. Community members perceived offenders who committed more (versus less) severe sex offenses as significantly more threatening, $B=1.54, t(158)=10.02, p<$ .001 and were more morally outraged about the offenders, $B=1.04, t(159)=5.93, p<.001$. When offense severity, perceived threat, and moral outrage were simultaneously entered as predictors of support for registry laws, the effect of offense severity was no longer significant, $\mathrm{OR}=2.10, z=1.57$, $n s$, indicating full mediation. Perceived threat, $\mathrm{OR}=3.87, z=4.61, p<.001$, and moral outrage, $\mathrm{OR}=$ 
$1.65, z=2.08, p<.05$, still significantly predicted support for registry laws. Thus, community members perceived juvenile sex offenders who commit more (versus less) severe offenses as significantly more threatening and were more morally outraged by them, both of which in turn led to greater likelihood of supporting registry laws.

Single mediator model for undergraduates. A series of regressions confirmed that undergraduates were significantly more likely to support harsher registry laws for offenders who committed more severe as compared to less severe sex offenses, $\mathrm{OR}=19.23, z=7.71, p<.001$. Undergraduates also perceived offenders who committed more (versus less) severe sex offenses as significantly more threatening, $B=1.42, t(379)=11.10, p<.001$. When offense severity and perceived threat were simultaneously entered as predictors of support for registry laws, the effect of offense severity was still significant, $\mathrm{OR}=4.22, z=3.34, p=.001$. But the offense severity odds ratio dropped from 19.23 to 4.22 - a significant drop indicating partial mediation, Sobel $z=4.49, p<.001$. Greater perceived threat was associated with significantly greater likelihood of supporting harsher registry laws, $\mathrm{OR}=4.91, z=9.05, p<.001$. Thus, undergraduates perceived juvenile sex offenders who commit more (versus less) severe offenses as significantly more threatening, which in turn led to greater likelihood of supporting registry laws.

\section{Study 3 Summary and Discussion}

As we theorized, the high level of general support for registry laws displayed in Studies 1 and 2-in which participants considered cases in the abstract - was attenuated when participants read about specific cases that were less severe or involved younger juveniles. As expected, we found that laypeople were less supportive of registry laws for less severe offenses compared to more severe offenses, and for a younger compared to an older juvenile sex offender. Thus, when people either naturally envision a less severe sex offender prototype or when they consider a specific case involving a less severe sex offender prototype, they are less supportive of juvenile sex offender registration. Further, Study 3 revealed that the effects of crime severity on community members' registry support 
were driven by both perceptions of threat to public safety and by feelings of moral outrage. Thus, laypeople's support for registry laws does not apply to all juvenile cases, and instead depends on case factors (i.e., offense severity and offender age).

This study is consistent with prior research finding that, for nonsexual offenses, public attitudes about sentencing in the abstract are more punitive than attitudes about sentencing applied to specific cases (Applegate et al., 1996; Brank, et al., 2006; Moon et al., 2000; Zamble \& Kalm, 1990). We also found that when participants are asked about sex offenders in general, the majority tend to envision a severe offense, which made them more likely to support harsher registry laws than people who envisioned a less severe offense. Support for registry laws for a juvenile who committed a more severe sex offense (i.e., rape) was very similar to the levels of support found in (a) Study 1 among participants who were asked to think about sex offenders in the abstract and (b) Study 2 among participants who imagined more severe prototypes of sex offenders. Thus, it appears that people have general, non-casespecific support for registry laws because they have a prototype of sex offenders (of all ages) as predators who commit heinous crimes. When they consider specific cases, however, people probably do not rely on their prototype and are therefore sensitive to the nature of the offense committed and less likely to support harsh registry laws when juveniles commit less compared to more severe offenses. In fact, nearly two-thirds of participants thought that a juvenile who committed a less severe offense (i.e., child pornography, sexual harassment, statutory rape) should never be required to register. Contrast this with Study 2, in which not one participant who was thinking of juvenile sex offenders in the abstract (even those in the minority who spontaneously imagined a less severe prototype) thought that never registering was an appropriate outcome.

Consistent with the results of Study 1 and Study 2, the effect of offense severity on support for registry laws was mediated by perceived threat to public safety (i.e., utilitarian concerns). In Study 3, however, we also found evidence of mediation by moral outrage (i.e., retributive concerns). Although utilitarian concerns for societal safety drove the creation and implementation of sex offender registry 
laws (Salerno et al., in press), these concerns do not appear to be as relevant to the public in cases in which juveniles commit less severe offenses or who are especially young. Furthermore, utilitarian goals are not the sole motivation for registry support - retributive goals of punishing sex offenders also helped explain support for registry laws for more severe juvenile sex offenses, a desire that is antithetical to the goals of the juvenile justice system (Reppucci et al., 2009). Note that moral outrage did not drive registry support in Study 2, when participants were asked about their desire to punish sex offenders as an abstract group as opposed to specific individuals, as in Study 3. It might be more difficult to estimate one's feelings of outrage and need to punish when considering an abstract group than when considering a specific individual whose actions are known.

\section{General Discussion}

For the first time, we explored public support for the recent extension of sex offender registry laws to juveniles. In the abstract, the public is as likely to support registry laws for juvenile as for adult sex offenders. But when faced with a particularly young juvenile, or a juvenile whose offenses are less severe than the prototypically severe sex offense that people naturally envision, people are less likely to support registry laws for juveniles than for adults.

Our results have implications for current policies and law. For example, in many states, registration for juvenile sex offenders is mandatory and judges may not exercise discretion based on offense severity (Salerno et al., in press). Consider such laws applied to cases involving offenses such as "sexting," a term coined for juveniles sending naked pictures of themselves to each other (as in our Study 3 child pornography condition). In several states, juveniles are currently required to register for this offense, a punishment questioned in Newsweek, CNN, and other major news sources. Even the mother of Megan Kanka, who was brutally raped, murdered, and after whom "Megan's Law” is named, has spoken out against registering juveniles for such relatively minor crimes (“Megan's Law Mom," 2009). Our results suggest that these policies are not entirely consistent with public sentiment either, which should help alleviate policymakers' fear of disappointing their constituents by 
questioning the utility of these policies.

We also found that social psychological theories regarding utilitarian and retributive concerns are useful for understanding support for registry laws. First, we found that under certain conditions (when a juvenile is older, when an offense is severe, or when people's imagined prototype of a sex offender is particularly negative), people believe an offender poses a significant threat to public safety, and in turn, their support for the registry rises. This mechanism is consistent with policymakers' rationale for creating these laws - to protect the community from sex offenders' future offenses. Second, although we consistently found that with increased offender age, prototype severity, and offense severity, people also had more feelings of moral outrage and desire to punish offenders, this increase in moral outrage translated into increased support for registry laws only when participants considered a specific offender instead of offenders in the abstract. This makes an interesting contribution to social psychological research on retributive motives - moral outrage and desire to punish might play a pivotal role in sentencing decisions only when people consider specific individuals rather than abstract groups. (Yet, as we have noted earlier, these retributive concerns are not consistent with historical intentions behind laws and policies for juvenile offenders.)

Along with prior research regarding nonsexual offenses (Applegate et al., 1996; Brank, et al., 2006; Moon et al., 2000; Zamble \& Kalm, 1990), our results reveal the importance of asking our participants to make judgments about abstract versus specific offenders. This allowed us to discover that, when asked in the abstract about even juvenile offenses, people are more likely to envision severe cases and therefore support harsh registry laws. Thus, research and public polls (which policymakers might rely on to gauge public sentiment) that simply ask people about policies in the abstract will artificially inflate and oversimplify estimates of how supportive people are of these laws. This has important applied implications, but also important theoretical implications — had we not asked about support for registering specific juvenile offenders, we would not have found that retributive motives can drive registry support. That is, moral outrage did not mediate judgments when participants were 
asked about abstract offenders, but did when asked about specific offenders. Thus, public opinion about abstract groups might reflect support for the most heinous criminals, misrepresenting their support for cases that do not fit the severe prototype people naturally envision. This is a particularly important issue to understand as researchers seek to determine public support for laws and policies directed at juvenile offenders.

\section{Strengths and Limitations}

A strength of our methodology is that we used stimulus materials based on actual cases. Future research on perceptions of specific juvenile offenders should incorporate more detailed and realistic stimulus materials, but our scenarios, based on actual cases, represent an important first step in research on this important topic. Another strength of our work is that we used a number of different samples, ranging from a particularly ethnically diverse group of undergraduates to community members and attorneys. Even so, future work could fruitfully examine support for sex offender policies among judges, policymakers, and others, and investigate factors that were beyond the scope of the present investigation such as offender characteristics, victim characteristics, or individual differences among perceivers that might also influence support for sex offender registration laws.

\section{Conclusion}

Juvenile sex offenses, including severe offenses such as forcible rape, are on the rise (Sickmund, 2009), and it is important to ensure public protection from all offenders, including juvenile offenders. Although the sex offender registry was created to fulfill this goal, social science research suggests that juvenile recidivism is lower than adult recidivism and that the registry might not be an effective method for preventing recidivism. And our research shows, for the first time, that the public does not support registry laws for all juvenile sex offenders. This is important to understand, because the movement to include juveniles on the registry might be fueled by politicians' and policymakers' assumption that the public supports these policies for juveniles across the board, an assumption we have shown to be faulty. 


\section{References}

Adkins, G., Huff, D., \& Stageberg, P. (2000). The Iowa sex offender registry and recidivism. Des Moines: Iowa Department of Human Rights.

Alexander, M. A. (1999). Sexual offender treatment efficacy revisited. Sexual abuse: A journal of research and treatment, 11, 101-116.

Applegate, B. K., Cullen, F. T., Turner, M. G., \& Sundt, J. L. (1996). Assessing public support for three-strikes-and-you're-out laws: Global versus specific attitudes. Crime \& Delinquency, 42, $517-534$.

Baron, R. M., \& Kenny, D. A. (1986). The moderator-mediator variable distinction in social psychological research: Conceptual, strategic, and statistical considerations. Journal of Personality and Social Psychology, 51, 1173-1182.

Bornstein, B. (1999). The ecological validity of jury simulations: Is the jury still out? Law and Human Behavior, 23, 75-91.

Brank, E. M., Hays, S. A., \& Weisz, V. (2006). All parents are to blame (except this one): Global versus specific attitudes related to parental responsibility laws. Journal of Applied Social Psychology, 36, 2670-2684.

Brenton, S. (2008, May 28). Fallon Campaign: Sex offender law makes children less safe - Fallon was right! [Press release]. Retrieved on March 9, 2009 from www.iowapolitics.com

Caldwell, M. F. (2009). Study characteristics and recidivism base rates in juvenile sex offender recidivism. International Journal of Offender Therapy and Comparative Criminology. Advance online publication. Retrieved June 12, 2009, doi: 10.1177/0306624X08330016

Caputo, A. A., \& Brodsky, S. L. (2004). Citizen coping with community notification of released sex offenders. Behavioral Sciences and the Law, 22, 239-252.

Carlsmith, K. M., Darley, J. M., \& Robinson, P. H. (2002). Why do we punish?: Deterrence and just deserts as motives for punishment. Journal of Personality and Social Psychology, 83, 284-299. 
Cauffman, E., \& Steinberg, L. (2000). (Im)maturity of Judgment in adolescence: Why adolescents may be less culpable than adults. Behavioral Sciences and the Law, 18, 741-760.

Chaffin, M. (2008). Our minds are made up—Don't confuse us with the facts: Commentary on policies concerning children with sexual behavior problems and juvenile sex offenders. Child Maltreatment, 13, 110-121.

Darley, J. M., Carlsmith, K. M., \& Robinson, P. H. (2000). Incapacitation and just deserts as motives for punishment. Law and Human Behavior, 24, 659-683.

Finkel, N. J., \& Groscup, J. L. (1997). Crime prototypes, objective versus subjective culpability, and a commonsense balance. Law and Human Behavior, 21, 209-230.

Goldsmith, S. (2007, July 22). Unruly schoolboys or sex offenders. The Oregonian, p. A01.

Haegerich, T. M., \& Bottoms, B. L. (2004, March). Effect of jurors'stereotypes of juvenile offenders on pre- and post-deliberation case judgments. Paper presented at the biennial meeting of the American Psychology-Law Society, Scottsdale, AZ.

Hanson, R. K., \& Bussiere, M. T. (1998). Predicting relapse: A meta-analysis of sexual offender recidivism studies. Journal of Consulting and Clinical Psychology, 66, 348-362.

Illinois State Police. (2006). A guide to sex offender registration and community notification in Illinois. Retrieved on October 27, 2009, from http://www.isp.state.il.us/docs/4-084d.pdf

Kernsmith, P. D., Craun, S. W., \& Foster, J. (2009). Public attitudes toward sexual offenders and sex offender registration. Journal of Child Sexual Abuse, 18, 290-301.

Krahe, B. (1991). Police officers' definitions of rape: A prototype study. Journal of Community \& Applied Social Psychology, 1, 223-244.

Letourneau, E. J., \& Armstrong, K. S. (2008). Recidivism rates for registered and nonregistered juvenile sexual offenders. Sexual Abuse: A Journal of Research and Treatment, 20, 393-408.

Letourneau, E. J., Bandyopadhyay, D., Sinha, D., \& Armstrong, K. (2009). Effects of sex offender registration policies on juvenile justice decision making. Sexual Abuse: A Journal of Research 
and Treatment, 21, 149-165.

Letourneau, E. J., \& Miner, M. (2005). Juvenile sex offenders: A case against the legal and clinical status quo. Sexual Abuse: Journal of Research and Treatment, 17, 293-312.

Levenson, J., Brannon, Y., Fortney, T., \& Baker, J. (2007). Public perceptions about sex offenders and community protection policies. Analyses of Social Issues and Public Policy, 7, 1-25.

Levenson, J., \& Cotter, L. (2005). The effect of Megan's law on sex offender reintegration. Journal of Contemporary Criminal Justice, 21, 49-66.

Levenson, J. S., D’Amora, D. A., \& Hern, A. L. (2007). Megan's Law and its impact on community re-entry for sex offenders. Behavioral Sciences and the Law, 25, 587-602.

Levesque, R. J. (1996). Is there still a place for violent youth in juvenile justice? Aggression and Violent Behavior, 1, 69-79.

'Megan's Law' mom criticizes 'sexting' charges. (2009, March 26). National Public Radio. Retrieved on May 27, 2009, from http://www.npr.org/templates/story/story.php?storyId=102399198

Moon, M. M., Sundt, J. L., Cullen, F. T., \& Wright, J. P. (2000). Is child saving dead? Public support for juvenile rehabilitation. Crime \& Delinquency, 46, 38-60.

No Easy Answers: Sex Offender Laws in the US. (2007, September). Human Rights Watch, 19. Retrieved on January 7, 2009 from http://www.hrw.org/en/reports/2007/09/11/no-easy-answers Phillips, D. (1998). Community notification as viewed by Washington's citizens. Olympia, WA: Washington State Institute for Public Policy.

Proctor, J. L., Badzinski, D. M., \& Johnson, J. (2002). The impact of media on knowledge and perceptions of Megan's Law. Criminal Justice Policy Review, 13, 356-379.

Proeve, M. J., \& Howells, K. (2006). Effects of remorse and shame and criminal justice experience on judgments about a sex offender. Psychology, Crime, \& Law, 12, 145-161.

Quinn, J. F., Forsyth, C. J., \& Mullen-Quinn, C. (2004). Societal reaction to sex offenders: A review of the origins and results of the myths surrounding their crimes and treatment amenability. 
Deviant Behavior, 25, 215-232.

Redlich, A. D. (2001). Community notification: Perceptions of its effectiveness in preventing child sexual abuse. Journal of Child Sexual Abuse, 10, 91-116.

Reppucci, N. D., Michel, J. L., \& Kostelnik, J. O. (2009). Challenging juvenile transfer: Faulty assumptions and misguided policies. In B. L. Bottoms, C. J. Najdowski, \& G. S. Goodman (Eds.), Children as victims, witnesses, and offenders: Psychological science and the law (pp. 295-312). New York: Guilford.

Robbers, M. L. P. (2009). Lifers on the outside: Sex offenders and disintegrative shaming. International Journal of Offender Therapy and Comparative Criminology, 53, 5-28.

Sahlstrom, K. J., \& Jeglic, E. L. (2008). Factors affecting attitudes toward juvenile sex offenders. Journal of Child Sexual Abuse, 17, 180-196.

Salerno, J. M., Stevenson, M. C., Wiley, T. R. A., Najdowski, C. J., Bottoms, B. L., \& Schmillen, R. A. (in press). Public attitudes toward applying sex offender registration laws to juvenile offenders. In J. M. Lampinen \& K. Sexton-Radek (Eds.), Protecting children from violence: Evidence based interventions. New York: Psychology Press.

Sample, L. L., \& Kadleck, C. (2008). Sex offender laws: Legislators' accounts of the need for policy. Criminal Justice Policy Review, 19, 40-62.

Sandler, J. C., Freeman, N. J., \& Socia, K. M. (2008). Does a watched pot boil? A time-series analysis of New York State's sex offender registration and notification law. Psychology, Public Policy, and Law, 14, 284-302.

Schiavone, S. K., \& Jeglic, E. L. (2008). Public perception of sex offender social policies and the impact on sex offenders. International Journal of Offender Therapy and Comparative Criminology.Advance online publication. Retrieved October 15, 2009, doi: 10.1177/0306624X08323454

Schram, D. D., \& Milloy, C. D. (1995). Community notification: A study of offender characteristics 
and recidivism. Olympia, WA: Washington State Institute for Public Policy.

Scott, E., Reppucci, N., Antonishak, J., \& DeGennaro, J. (2006). Public attitudes about the culpability and punishment of young offenders. Behavioral Sciences and the Law, 24, 815-832.

Sickmund, M. (2009). Delinquency cases in juvenile court, 2005. Washington, DC: U.S. Department of Justice.

Skitka, L. J. (2002). Do the means always justify the ends, or do the ends sometimes justify the means? A value model of justice reasoning. Personality and Social Psychology Bulletin, 28, 588-597.

Skitka, L. J., Bauman, C. W., \& Mullen, E. (2004). Political tolerance and coming to psychological closure following the September 11, 2001, terrorist attacks: An integrative approach. Personality and Social Psychology Bulletin, 30, 743-756.

Skitka, L. J., \& Mullen, E. (2002). Understanding judgments of fairness in a real-world political context: A test of the value protection model of justice reasoning. Personality and Social Psychology Bulletin, 28, 1419-1429.

Smith, V. L. (1991). Prototypes in the courtroom: Lay representations of legal concepts. Journal of Personality and Social Psychology, 61, 857-872.

Stalans, L. J. (1993). Citizen's crime stereotypes, biased recall, and punishment preferences in abstract cases: The educative role of interpersonal sources. Law and Human Behavior, 17, 451-470.

Stalans, L. J., \& Diamond, S. S. (1990). Formation and change in lay evaluation of criminal sentencing. Law and Human Behavior, 14, 199-214.

Stevenson, M. C., Sorenson, K. M., Smith, A. C., Sekely, A., \& Dzwairo, R. A. (in press). Effects of defendant and victim race on perceptions of juvenile sex offenders. Behavioral Sciences and the Law.

Stockinger, J. (2009, March 26). Nude photos at St. Charles East lead to arrest. Daily Herald. Retrieved on March 31, 2009 at: http://www.dailyherald.com/story/?id=281904\&src=5

Tewksbury, R. (2005). Collateral consequences of sex offender registration. Journal of Contemporary 
Criminal Justice, 21, 67-81.

Tewksbury, R., \& Lees, M. (2006). Perceptions of sex offender registration: Collateral consequences and community experiences. Sociological Spectrum, 26, 309-334.

The Adam Walsh Child Protection and Child Safety Act of 2006, 42 U.S.C. $§ 16911$ (2006), Pub. L. No. 109-248, 120 Stat. 587 (codified in various sections of 42 U.S.C.).

Trivits, L., \& Reppucci, N. (2002). Application of Megan's Law to juveniles. American Psychologist, 57, 690-704.

U.S. Department of Justice. (June, 2007). Criminal offender statistics. (Office of Justice Programs, Bureau of Justice Statistics). Retrieved on June 26, 2009 from http://www.ojp.usdoj.gov/bjs/crimoff.htm.

Vidal, S., \& Skeem, J. L. (2007). Effect of psychopathy, abuse, and ethnicity on juvenile probation officers' decision-making and supervision strategies. Law and Human Behavior, 31, 479-498.

Weiner, B. (2006). Social motivation, justice, and the moral emotions: An attributional approach. Mahwah, NJ: Lawrence Erlbaum Associates.

Wiley, T. R. A., \& Bottoms, B. L. (2009). Effects of defendant sexual orientation on jurors' perceptions of child sexual assault. Law and Human Behavior, 33, 46-60.

Wilson v. State, 279 Ga. App. 459 (2006).

Zamble, E., \& Kalm, K. L. (1990). General and specific measures of public attitudes toward sentencing. Canadian Journal of Behavioural Science, 22, 327-337. 


\section{Footnotes}

${ }^{1}$ Some participants did not indicate their age on the questionnaires, probably because they just missed the question. We included these participants (Study 1, $n=48$; Study 2, $n=10$; Study 3, $n=12$ ) in all analyses. Only $4 \%(n=6)$ of the community members who answered the age question were under the age of 18 , thus it is unlikely that many of the participants who left this question blank were underaged. We included these participants in all analyses because the number of participants we would have had to drop to exclude all who missed the age question is relatively high and dropping them would reduce our statistical power and threaten random assignment of participants to condition.

${ }^{2}$ One might question whether these excluded participants differed in some significant way from the other participants. We conducted a separate series of regression analyses dropping the independent variable of sex offender prototype and including only the independent variable of offender age, first with and then without the excluded participants. The pattern and significance level of the offender age effect on support for registry laws, perceived threat, and moral outrage did not change. 
Table 1

Sample Descriptives

\begin{tabular}{|c|c|c|c|c|c|c|c|}
\hline & \multicolumn{4}{|c|}{$\begin{array}{l}\text { Study } 1 \\
N=472\end{array}$} & \multirow{2}{*}{$\begin{array}{c}\begin{array}{c}\text { Study } 2 \\
N=104\end{array} \\
\text { Undergraduates }\end{array}$} & \multicolumn{2}{|c|}{$\begin{array}{l}\text { Study } 3 \\
N=546\end{array}$} \\
\hline & $\begin{array}{c}\text { Family law } \\
\text { attorneys } \\
(n=57)\end{array}$ & $\begin{array}{l}\text { Community } \\
\text { members } \\
(n=224)\end{array}$ & $\begin{array}{l}\text { Prosecuting } \\
\text { attorneys } \\
(n=37)\end{array}$ & $\begin{array}{l}\text { Undergraduates } \\
\qquad(n=154)\end{array}$ & & $\begin{array}{l}\text { Community } \\
\text { members } \\
(n=164)\end{array}$ & $\begin{array}{l}\text { Undergraduates } \\
\quad(n=382)\end{array}$ \\
\hline Gender ( $\%$ women $)$ & $39 \%$ & $55 \%$ & $54 \%$ & $66 \%$ & $51 \%$ & $54 \%$ & $56 \%$ \\
\hline Mean age in years $(S D)^{1}$ & $51(13)$ & $37(13)$ & $40(6)$ & $19(2)$ & $19(1)$ & $42(16)$ & $19(1)$ \\
\hline \multicolumn{8}{|l|}{ Ethnicity } \\
\hline African American & $0 \%$ & $10 \%$ & $6 \%$ & $12 \%$ & $12 \%$ & $12 \%$ & $7 \%$ \\
\hline Asian & $0 \%$ & $15 \%$ & $0 \%$ & $32 \%$ & $27 \%$ & $11 \%$ & $32 \%$ \\
\hline Hispanic & $2 \%$ & $14 \%$ & $3 \%$ & $12 \%$ & $25 \%$ & $8 \%$ & $19 \%$ \\
\hline White & $94 \%$ & $57 \%$ & $85 \%$ & $41 \%$ & $33 \%$ & $63 \%$ & $37 \%$ \\
\hline Other backgrounds & $4 \%$ & $3 \%$ & $6 \%$ & $4 \%$ & $3 \%$ & $6 \%$ & $5 \%$ \\
\hline
\end{tabular}


Table 2

Study 1: Support for Registry Laws and Perceived Safety Threat as a Function of Offender Age and Sample

\begin{tabular}{|c|c|c|c|}
\hline \multirow[b]{2}{*}{ Sample } & \multicolumn{2}{|c|}{ Offender Age } & \multirow[b]{2}{*}{ Marginal } \\
\hline & Juvenile & Adult & \\
\hline Support for registry laws & $\%$ & $\%$ & $\%$ \\
\hline \multicolumn{4}{|l|}{ Family law attorneys } \\
\hline Never register & $35 \%$ & $3 \%$ & $17 \%$ \\
\hline Register but not online & $39 \%$ & $38 \%$ & $39 \%$ \\
\hline Register online & $26 \%$ & $59 \%$ & $44 \%$ \\
\hline \multicolumn{4}{|l|}{ Community members } \\
\hline Never register & $4 \%$ & $3 \%$ & $3 \%$ \\
\hline Register but not online & $28 \%$ & $21 \%$ & $24 \%$ \\
\hline Register online & $69 \%$ & $77 \%$ & $72 \%$ \\
\hline \multicolumn{4}{|l|}{ Prosecuting Attorneys } \\
\hline Never register & $0 \%$ & $0 \%$ & $0 \%$ \\
\hline Register but not online & $19 \%$ & $0 \%$ & $11 \%$ \\
\hline Register online & $81 \%$ & $100 \%$ & $89 \%$ \\
\hline \multicolumn{4}{|l|}{ Undergraduates } \\
\hline Never register & $6 \%$ & $3 \%$ & $5 \%$ \\
\hline Register but not online & $14 \%$ & $21 \%$ & $17 \%$ \\
\hline Register online & $80 \%$ & $77 \%$ & $78 \%$ \\
\hline \multicolumn{4}{|l|}{ Marginal } \\
\hline Never register & $7 \%$ & $3 \%$ & $5 \%$ \\
\hline Register but not online & $23 \%$ & $21 \%$ & $22 \%$ \\
\hline Register online & $70 \%$ & $76 \%$ & $73 \%$ \\
\hline Perceived safety threat & $M(S D)$ & $M(S D)$ & $M(S D)$ \\
\hline Family law attorneys & $2.51(.62)$ & $3.31(.73)$ & $2.94(.63)$ \\
\hline Community members & $3.31(.66)$ & $3.80(.71)$ & $3.55(.74)$ \\
\hline Prosecuting attorneys & $3.88(.66)$ & $4.42(.54)$ & $4.11(.66)$ \\
\hline Undergraduates & $3.21(.55)$ & $3.49(.68)$ & $3.34(.63)$ \\
\hline Marginal & $3.24(.71)$ & $3.68(.74)$ & $3.45(.76)$ \\
\hline
\end{tabular}

Note. Perceived safety threat was measured on a scale ranging from 1 (strongly disagree) to 5 (strongly agree). 
Table 3

Support for Registry Laws in Study 2 and Study 3 as a function of Offender Age/Juvenile Offender Age and Prototype/Offense Severity

\begin{tabular}{|c|c|c|c|c|c|c|}
\hline \multirow[b]{3}{*}{ Prototype/Offense severity } & \multicolumn{3}{|c|}{ Study 2} & \multicolumn{3}{|c|}{ Study 3} \\
\hline & \multicolumn{2}{|c|}{ Offender age } & \multirow[b]{2}{*}{ Marginal } & \multicolumn{2}{|c|}{ Juvenile offender age } & \multirow{3}{*}{$\begin{array}{c}\text { Marginal } \\
\%\end{array}$} \\
\hline & Juvenile & Adult & & 12-year-old & 16-year-old & \\
\hline Support for registry laws & $\%$ & $\%$ & $\%$ & $\%$ & $\%$ & \\
\hline \multicolumn{7}{|l|}{ More severe } \\
\hline Never register & $8 \%$ & $0 \%$ & $4 \%$ & $3 \%$ & $5 \%$ & $4 \%$ \\
\hline Register but not online & $16 \%$ & $29 \%$ & $23 \%$ & $38 \%$ & $22 \%$ & $30 \%$ \\
\hline Register online & $76 \%$ & $71 \%$ & $73 \%$ & $59 \%$ & $73 \%$ & $66 \%$ \\
\hline \multicolumn{7}{|l|}{ Less severe } \\
\hline Never register & $0 \%$ & $14 \%$ & $6 \%$ & $73 \%$ & $59 \%$ & $66 \%$ \\
\hline Register but not online & $64 \%$ & $57 \%$ & $61 \%$ & $17 \%$ & $20 \%$ & $19 \%$ \\
\hline Register online & $36 \%$ & $29 \%$ & $33 \%$ & $10 \%$ & $20 \%$ & $15 \%$ \\
\hline \multicolumn{7}{|l|}{ Marginal } \\
\hline Never register & $7 \%$ & $4 \%$ & $5 \%$ & $63 \%$ & $51 \%$ & $59 \%$ \\
\hline Register but not online & $26 \%$ & $31 \%$ & $28 \%$ & $20 \%$ & $21 \%$ & $20 \%$ \\
\hline Register online & $67 \%$ & $65 \%$ & $66 \%$ & $17 \%$ & $28 \%$ & $23 \%$ \\
\hline
\end{tabular}

Note. Study 3 results are collapsed across sample (community members, undergraduates). 